G.A. Salman

Ministry of Higher Education and Scientific Research, Reconstruction and Projects Directorate, Bagdad, Iraq. ghazwan_salman@yahoo .com

Received on: 26/01/2017 Accepted on: 08/06/2017

\section{Density and Ultrasonic Pulse Velocity Investigation of Self-Compacting Carbon Fiber- Reinforced Concrete}

\begin{abstract}
A comprehensive research has been carried out to understand the effect of adding carbon fibers to density and ultrasonic pulse velocity of self-compacting concrete. Fifteen SCC mixes were prepared with two types of mineral admixtures and carbon fibers. Metakaoline and silica fume were used as mineral admixtures while carbon fibers were used as fiber inclusions. Two different fiber length $(6 \mathrm{~mm}$ and $12 \mathrm{~mm}$ ) and fiber fraction (0.1\% and $0.5 \%)$ was used. Different parameters such as slump flow diameter, T500 time, V-funnel time, blocking ratio and filling height difference were used to evaluate fresh state properties. Air-dry density and Ultrasonic Pulse Velocity values are determined for mixes at age of 7, 28, 90 and 180 days. The experimental results indicate that concrete mixes contained carbon fiber showed higher air dry density than concrete mixes without fiber, the percentage increase were between $0.85 \%$ to $3.31 \%$ at age $(7,28,90$ and 180$)$ days respectively. Concrete mixes contained carbon fiber compared with the reference mixes without carbon fiber exhibits an increase in the ultrasonic pulse velocity values of about $0.74 \%$ to $5 \%$ at age $(7,28,90$ and 180$)$ days respectively.
\end{abstract}

Keywords ; SCC, carbon fibers, mineral admixture, ultrasonic pulse velocity

How to cite this article: G.A. Salman, " Density and Ultrasonic Pulse Velocity Investigation of Self-Compacting Carbon FiberReinforced Concrete," Engineering and Technology Journal, Vol. 36, Part A, No. 1, pp. 89-99, 2018.

\section{Introduction}

The most widely used materials of concrete industry in the near future is expected to be selfcompacting concrete (SCC). To better understand, extensive researches are being done to define and model the behavior of these materials. The important subjects are mix optimization, fresh state properties, issues such as static and dynamic segregation and resulting mechanical performance and each require special attention. The addition of carbon fibers to concrete are advantageous in many ways due to improvements of mechanical properties such as compressive strength, splitting tensile, modulus of elasticity, flexural strength ,toughness, impact resistance and fatigue resistance [1-4]. Nevertheless, unfortunately, test results concluded that carbon fibers alter fresh state properties of mixes [5-6]. The reason about why carbon fibers attractive to many researcher are their low density and thermal conductivity [5]. The extent of the negative effect caused by carbon fibers is also different. The combination of carbon fibers with selfcompacting concrete showed an improving in mechanical properties and electrical resistivity [7]. The addition of carbon fibers to self compacting concrete offers significant improvement to the mechanical properties such as flexural strength and toughness [7-10]. Many investigators attempted to propose the common limits for the ultrasonic pulse velocity to different type of concrete. The classifying of concretes are excellent, good, doubtful, poor, and very poor for $(4.8 \mathrm{~km} / \mathrm{s})$ and above, $(3.66-$ $4.57 \mathrm{~km} / \mathrm{s}), \quad(3.50-3.66 \mathrm{~km} / \mathrm{s}), \quad(2.14-3.0 \mathrm{~km} / \mathrm{s})$ and $(2.14 \mathrm{~km} / \mathrm{s})$ and below UPV values, respectively [11]. It was found that, a linear correlation between ultrasonic pulse velocity and air density represented by the equation $\mathrm{y}=$ $1506.9 \mathrm{x}+541.7\left(\mathrm{R}^{2}=88.69 \%\right)$, where $\mathrm{y}$ is the pulse velocity and $x$ the air density .The higher the pulse velocity the higher the air density of the cementations' composites [12]. This study aims to help the researcher about the effects of adding various volumes and aspect ratios of carbon fibers, on density and ultrasonic pulse velocity of self compacting carbon fiberreinforced concrete mixes by giving quantitative information. The percentage variations in the density and ultrasonic pulse velocity with addition of mineral admixtures, increasing fiber length, and fiber volume fraction will be investigated. The methods, which was explained in the European guidelines for self-compacting concrete [6], 
was used to assess fresh state performance. Local Iraqi natural sand and gravel were used as fine and coarse aggregate in this study. The grading and physical properties of fine and coarse aggregates are shown in Table 3 and 4 respectively. The high reactive metakaoline (HRM) and Silica fume (Elkem micro silica fume) were used in this study. The chemical and physical properties of silica fume and are listed in Table 5 and 6 respectively while Table
7 and 8 respectively showed chemical and physical properties of high reactive metakaoline (HRM). Glenium 51, which made for the production of high performance concrete, is used. Its relative density is 1.1 $\mathrm{g} / \mathrm{cm} 3 @ 20{ }^{\circ} \mathrm{C}$ and has a PH value of 6.6. Carbon fibers with two different lengths were used in this study. The Physical and mechanical properties of the fibers used are given in Table 9.

Table 1: Chemical Properties of Portland cement*

\begin{tabular}{lll}
\hline \hline Component (\%) & Cement & Limits of (I.Q.S.) No.5/1984 [13] \\
\hline $\mathrm{SiO}_{2}$ & 19.8 & - \\
$\mathrm{CaO}$ & 60.7 & - \\
$\mathrm{Al}_{2} \mathrm{O}_{3}$ & 1.4 & - \\
$\mathrm{Fe}_{2} \mathrm{O}_{3}$ & 3 & - \\
$\mathrm{MgO}$ & 5.68 & $<5.00$ \\
$\mathrm{SO}_{3}$ & 2.3 & $<2.80$ \\
$\mathrm{~L} . \mathrm{O} . \mathrm{I}$ & 1.45 & $<4.00$ \\
$\mathrm{I} . \mathrm{R}$ & 1.1 & $<1.5$ \\
$\mathrm{~L} . \mathrm{S} . \mathrm{F}$ & 0.84 & $0.66-1.02$ \\
\hline \multicolumn{3}{c}{} \\
\hline $\mathrm{C} 3 \mathrm{~S}$ & Main compounds (Bogue's equations) \\
$\mathrm{C} 2 \mathrm{~S}$ & 47.13 & - \\
$\mathrm{C} 3 \mathrm{~A}$ & 21.6 & - \\
$\mathrm{C} 4 \mathrm{AF}$ & 10 & - \\
\hline
\end{tabular}

* Chemical and physical analysis conducted by National Center for Construction Laboratories and Researches in Baghdad.

Table 2: Physical properties of cement

\begin{tabular}{lll}
\hline \hline Physical properties & Test result & Limits of Iraqi Specification No.5/1984 [13] \\
\hline $\begin{array}{l}\text { Specific surface area } \\
\text { (Blaine method), }\left(\mathrm{cm}^{2} / \mathrm{g}\right)\end{array}$ & 2850 & $\geq 2300$ \\
$\begin{array}{l}\text { Setting time (Vicat's method) } \\
\text { Initial setting time (min ) }\end{array}$ & 135 & $\geq 45 \mathrm{~min}$ \\
Final setting time (min ) & 205 & $\leq 10 \mathrm{hrs}$ \\
Compressive strength (MPa) & & \\
3 days & 17.38 & $\geq 15$ \\
7 days & 26.69 & $\geq 23$ \\
Soundness: Autoclave \% & 0.34 & $\leq 0.8$ \\
\hline
\end{tabular}

Table 3: Grading of fine and coarse aggregates

\begin{tabular}{|c|c|c|c|c|}
\hline \multirow{2}{*}{$\begin{array}{l}\text { Sieve } \\
\text { Size }(\mathrm{mm})\end{array}$} & \multicolumn{4}{|c|}{ \% passing by weight } \\
\hline & Sand & $\begin{array}{l}\text { Limits of the Iraqi } \\
\text { Specification } \\
\text { No.45/1984 zone (2) }\end{array}$ & Gravel & $\begin{array}{l}\text { Limits of the Iraqi Specification } \\
\text { No.45/1984 [14] }\end{array}$ \\
\hline 14 & & & 100 & $90-100$ \\
\hline 10 & & 100 & 83 & $50-85$ \\
\hline 4.75 & 100 & $90-100$ & 9 & $0-10$ \\
\hline 2.36 & 89.4 & $75-100$ & 2.2 & - \\
\hline 1.18 & 82.6 & $55-90$ & & \\
\hline 0.6 & 58.9 & $35-59$ & & \\
\hline 0.3 & 21 & $8-30$ & & \\
\hline 0.15 & 3.3 & $0-10$ & & \\
\hline
\end{tabular}


Table 4: Physical properties of the coarse and fine aggregate

\begin{tabular}{lll}
\hline \hline Physical properties & Gravel & Sand \\
\hline Specific gravity & 2.68 & 2.65 \\
Sulfate content & 0.08 & 0.05 \\
Absorption & $2.3 \%$ & 2 \\
\hline
\end{tabular}

Table 5: Chemical analysis of Silica Fume *

\begin{tabular}{lll}
\hline \hline Component (\%) & Silica Fume & ASTM C1240-05 [15] \\
\hline $\mathrm{SiO}_{2}$ & 94 & Min. 85\% \\
$\mathrm{CaO}$ & $\mathrm{Nil}$ & $<1 \%$ \\
$\mathrm{MgO}$ & 2.00 & --- \\
$\mathrm{Fe}_{2} \mathrm{O}_{3}$ & 1.32 & $<2.5 \%$ \\
$\mathrm{Al}_{2} \mathrm{O}_{3}$ & 2.03 & $<1 \%$ \\
$\mathrm{SO}_{3}$ & --- & $<1 \%$ \\
$\mathrm{~K}_{2} \mathrm{O}+\mathrm{Na}_{2} 0$ & 1.32 & $<3 \%$ \\
$\mathrm{L.O} . \mathrm{I}$ & 4.36 & $\mathrm{Max} .6 \%$ \\
$\mathrm{Cl}$ & 0.16 & $<0.2 \%$ \\
$\mathrm{CaO}$ (free) & 2.34 & $<4 \%$ \\
\hline
\end{tabular}

*Chemical and physical analysis conducted by National Center for Construction Laboratories and Researches in Baghdad.

Table 6: Physical properties of Silica Fume used

\begin{tabular}{lll}
\hline \hline Property & Result & $\begin{array}{l}\text { ASTM C1240-05 } \\
{[15]}\end{array}$ \\
\hline Strength activity index & 158.8 & $\geq 105$ \\
Specific gravity & 2.45 & - \\
Physical form & powder & - \\
Color & grey & - \\
Size & 0.15 & $\sim 0.15$ micron \\
Specific Surface area $\left(\mathrm{cm}^{2} / \mathrm{gm}\right)$ & 21000 & - \\
Moisture & $0 \%$ & $<2 \%$ \\
\hline
\end{tabular}

Table 7: Chemical analysis of High Reactive Metakaoline (HRM)*

\begin{tabular}{lll}
\hline \hline Component (\%) & High Reactive Metakoaline & Pozzolan class N (ASTM 618-03) [16] \\
\hline $\mathrm{SiO}_{2}$ & 51.34 & $70 \% \mathrm{Min}$. \\
$\mathrm{Fe}_{2} \mathrm{O}_{3}$ & 2.3 & \\
$\mathrm{Al}_{2} \mathrm{O}_{3}$ & 33.4 & \\
$\mathrm{CaO}$ & 3 & \\
$\mathrm{MgO}$ & 0.17 & $1.5 \mathrm{Max}$ \\
$\mathrm{Na}$ & & $1.5 \mathrm{Max}$ \\
$\mathrm{SO}_{3} \mathrm{O}$ & 0.15 & $4 \% \mathrm{Max}$. \\
$\mathrm{K} 2 \mathrm{O}$ & & $10 \mathrm{Max}$. \\
$\mathrm{L.O} . \mathrm{I}$ & 7.8 & .
\end{tabular}

*Chemical and physical analysis conducted by National Center for Construction Laboratories and Researches in Baghdad.

Table 8: Physical properties of High Reactive Metakaoline (HRM)*

\begin{tabular}{lll}
\hline \hline Physical Properties & Result & Pozzolan class N[16] \\
\hline Strength activity index & 164.5 & 70 \\
Specific gravity & 2.62 & - \\
Physical form & powder & - \\
Color & off - white & - \\
Specific Surface area $\left(\mathrm{cm}^{2} / \mathrm{gm}\right)$ & 19000 & - \\
Moisture & $0 \%$ & $<2 \%$ \\
\hline T Tests were carried out at State Company of Geological Survey and Mining.
\end{tabular}


Table 9: Physical and mechanical properties of the used fibers [17]

\begin{tabular}{ll}
\hline \hline Physical properties & Result \\
\hline Specific gravity $\left(\mathrm{gm} / \mathrm{cm}^{3}\right)$ & 1.78 \\
Young modulus(GPA) & 231 \\
Tensile strength(MPA) & 4100 \\
Elongation at break $(\%)$ & 1.7 \\
Design thickness $(\mathrm{mm})$ & 0.12 \\
Fiber length(mm) & $6 \alpha 12$ \\
Aspect ratio $(\mathrm{l} / \mathrm{d})$ & $50 \alpha 100$ \\
\hline
\end{tabular}

\section{Mixture Proportions}

Fifteen concrete mixes were prepared with different cementations materials constitutions. The cement dosages were kept constant at $500 \mathrm{~kg} / \mathrm{m}^{3}$. All reference concrete mixes made with concrete mix of (1:2.08:0.96) (cement fine aggregate: coarse aggregate) in proportion by weight and $(0.35)$ water/cement ratio were used. The Silica fume in some mixes was added by $10 \%$ by weight of cement while Metakaoline were added in others with the same ratio. The super plasticizer dosage was $8 \%$ by weight of cement for SCC mix made without mineral admixtures while SCC mixes containing Silica fume the dosage become $9 \%$ and SCC mixes containing metakaoline become $10 \%$ by weight of cement .The w/cement or w/binder ratio become (0.39) and The super plasticizer dosage become $12 \%$, $14 \%$ and $13 \%$ by weight of cement for SCC mixes made without mineral admixtures, containing Silica fume and containing metakaoline respectively with different carbon fibers length or content. This increase properly to maintain self-compacting ability within the given limits [6]. Table 10 show the mixture proportions of all concrete mixes.

Table 10. Mixture proportions of concrete*

\begin{tabular}{|c|c|c|c|c|c|c|c|}
\hline Mix & Mixture code & $\begin{array}{l}\text { Cement:Sand:Gravel } \\
\text { [ratio by weight] }\end{array}$ & 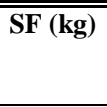 & $\begin{array}{l}\text { HRM } \\
(\mathbf{k g})\end{array}$ & $\begin{array}{l}\text { Fiber } \\
\text { Length } \\
(\mathrm{mm})\end{array}$ & $\begin{array}{ll}\text { Vf } & (\%)\end{array}$ & $\begin{array}{l}\text { Sp (\%) of } \\
\text { Cement } \\
\text { weight }\end{array}$ \\
\hline 1 & SCC & $\begin{array}{l}1: 2.08: 0.96 \\
1040 \\
480\end{array}$ & - & - & - & - & 8 \\
\hline 2 & SCCS & $\begin{array}{l}1: 2.08: 0.96 \\
1040 \\
480\end{array}$ & - & 50 & - & - & 9 \\
\hline 3 & SCCM & $\begin{array}{l}1: 2.08: 0.96 \\
1040 \\
480\end{array}$ & 50 & - & - & - & 10 \\
\hline 4 & SCC0.1C6 & $\begin{array}{l}1: 2.08: 0.96 \\
1040 \\
480\end{array}$ & - & - & 6 & 0.1 & 12 \\
\hline 5 & SCCS0.1C6 & $\begin{array}{l}1: 2.08: 0.96 \\
1040 \\
480\end{array}$ & - & 50 & 6 & 0.1 & 13 \\
\hline 6 & SCCM0.1C6 & $\begin{array}{l}1: 2.08: 0.96 \\
1040 \\
480\end{array}$ & 50 & - & 6 & 0.1 & 14 \\
\hline 7 & $\mathrm{SCC} 0.1 \mathrm{C} 12$ & $\begin{array}{l}1: 2.08: 0.96 \\
1040 \\
480\end{array}$ & - & - & 12 & 0.1 & 12 \\
\hline 8 & SCCS0.1C12 & $\begin{array}{l}1: 2.08: 0.96 \\
1040 \\
480\end{array}$ & - & 50 & 12 & 0.1 & 13 \\
\hline 9 & SCCM0.1C12 & $\begin{array}{l}1: 2.08: 0.96 \\
1040 \\
480\end{array}$ & 50 & - & 12 & 0.1 & 14 \\
\hline 10 & SCC0.5C6 & $\begin{array}{l}1: 2.08: 0.96 \\
1040 \\
480\end{array}$ & - & - & 6 & 0.5 & 12 \\
\hline 11 & SCCS0.5C6 & $\begin{array}{l}1: 2.08: 0.96 \\
1040 \\
480\end{array}$ & - & 50 & 6 & 0.5 & 13 \\
\hline 12 & SCCM0.5C6 & $\begin{array}{l}1: 2.08: 0.96 \\
1040 \\
480\end{array}$ & 50 & - & 6 & 0.5 & 14 \\
\hline 13 & MC0.5C12 & $\begin{array}{l}1: 2.08: 0.96 \\
1040 \\
480\end{array}$ & - & -- & 12 & 0.5 & 12 \\
\hline 14 & MCS0.5C12 & $\begin{array}{l}1: 2.08: 0.96 \\
1040 \\
480\end{array}$ & - & 50 & 12 & 0.5 & 13 \\
\hline 15 & MCM0.5C12 & $\begin{array}{l}1: 2.08: 0.96 \\
480\end{array}$ & 50 & - & 12 & 0.5 & 14 \\
\hline
\end{tabular}




\section{I.Mixing and Curing}

The mixing procedure which proposed by Walraven and Grunewald [18] was used. The ingredients were mixed in an electrical pan mixer, which has a capacity of $0.1 \mathrm{~m} 3$. Then, materials were cast into steel moulds. After casting, specimens were placed immediately in moist cabinet maintained at a temperature of $23 \pm 2$ and a relative humidity of about $95 \%$ for
24 hours. After that, specimens were demolded and stored in tap water until the time of test.

\section{II.Applied Tests}

Fresh state Tests

Fresh state properties of concrete mixes were evaluated by using slump flow, V-funnel, Lbox and U-box tests. Shown in Figure (1. (a), (b), (c) and (d)) respectively

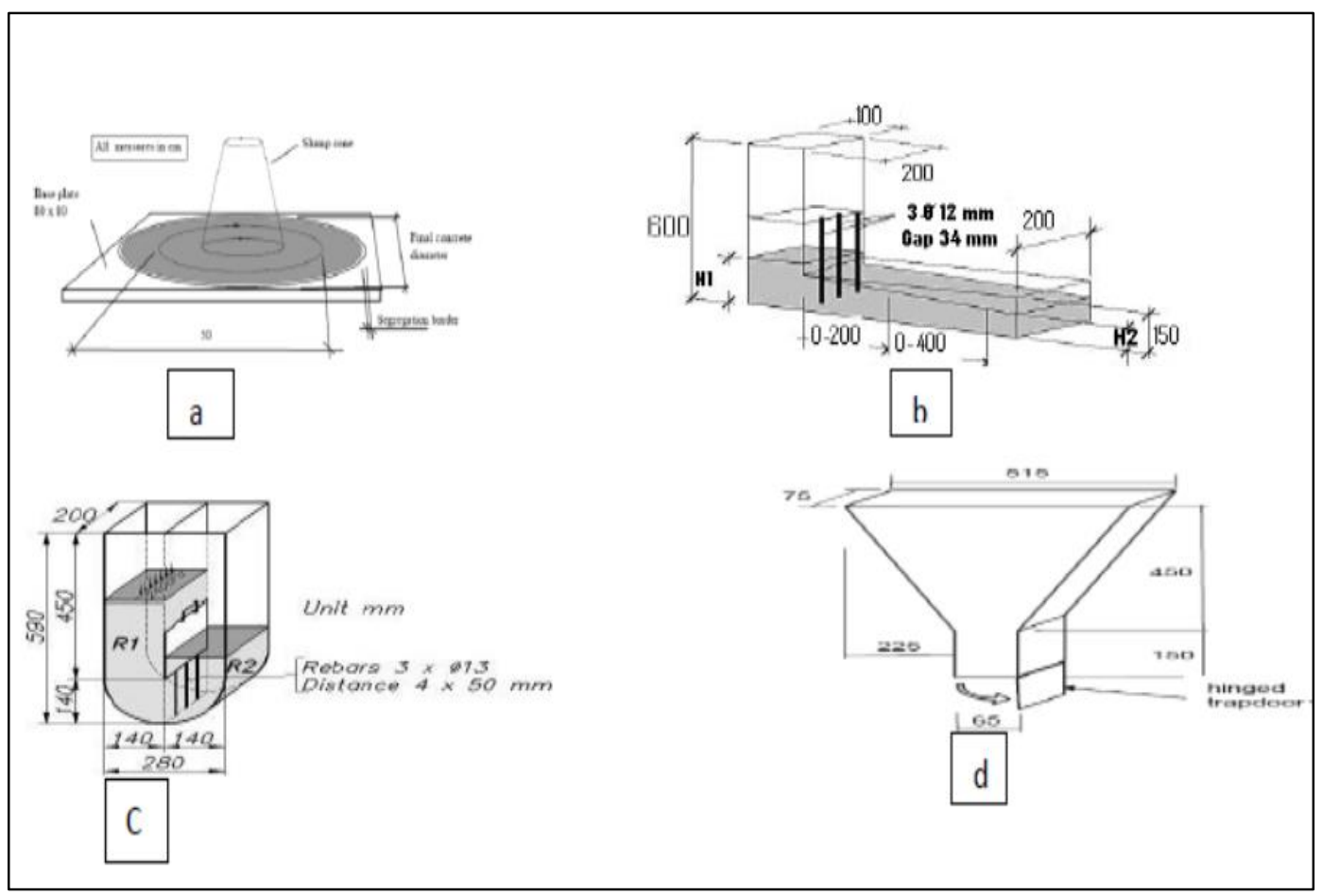

Figure 1. a) V-funnel b) L-box c) U box test set upHardened State Tests

Table 11 Results of fresh properties of SCC for all mixes

\begin{tabular}{lllllll}
\hline \hline Mix & $\begin{array}{l}\text { Mixture } \\
\text { code }\end{array}$ & $\begin{array}{l}\text { Slump } \\
\text { Flow } \\
(\mathbf{m m})\end{array}$ & $\begin{array}{l}\text { T500 } \\
\text { (Sec) }\end{array}$ & $\begin{array}{l}\text { Blocking } \\
\text { Ratio } \\
\text { (H2/H1) }\end{array}$ & $\begin{array}{l}\text { Filling Height } \\
\text { (R1-R2) }\end{array}$ & $\begin{array}{l}\text { V-Funnel } \\
\text { Time(Sec) }\end{array}$ \\
\hline $\mathbf{1}$ & SCC & 800 & 2.2 & 0.97 & 3 & 6.2 \\
$\mathbf{2}$ & SCCS & 795 & 2.3 & 0.95 & 5 & 6.4 \\
$\mathbf{3}$ & SCCM & 790 & 2.4 & 0.94 & 8 & 6.5 \\
$\mathbf{4}$ & SCC0.1C6 & 750 & 3.3 & 0.88 & 17 & 8.2 \\
$\mathbf{5}$ & SCCS0.1C6 & 744 & 3.4 & 0.875 & 18 & 8.4 \\
$\mathbf{6}$ & SCCM0.1C6 & 740 & 3.5 & 0.87 & 19 & 8.5 \\
$\mathbf{7}$ & SCC0.1C12 & 740 & 3.66 & 0.86 & 20 & 8.9 \\
$\mathbf{8}$ & SCCS0.1C12 & 736 & 3.70 & 0.856 & 21 & 9.2 \\
$\mathbf{9}$ & SCCM0.1C12 & 732 & 3.79 & 0.85 & 23 & 9.3 \\
$\mathbf{1 0}$ & SCC0.5C6 & 656 & 5.0 & 0.81 & 27 & 11.7 \\
$\mathbf{1 1}$ & SCCS0.5C6 & 653 & 5.06 & 0.82 & 28 & 11.8 \\
$\mathbf{1 2}$ & SCCM0.5C6 & 650 & 5.1 & 0.815 & 30 & 12.0 \\
$\mathbf{1 3}$ & MC0.5C12 & 612 & 6.4 & 0.71 & 36 & 15 \\
$\mathbf{1 4}$ & MCS0.5C12 & 605 & 6.7 & 0.72 & 41 & 16 \\
$\mathbf{1 5}$ & MCM0.5C12 & 602 & 6.8 & 0.714 & 40 & 18 \\
\hline
\end{tabular}




\section{III.The dry density}

The air-dry density of concrete was determined according to ASTM C 642-97 [19]. The air-dry density test was carried out at the concrete ages of 7 , $28,90,180$ days. The results obtained from three test $100 \mathrm{~mm}$ cubes were averaged to determine the air dry density of concrete. $100 \mathrm{~mm}$ cubes were used to determine the density. The density are calculated as follows:

Air density, dry $=[\mathrm{A} /(\mathrm{C}-\mathrm{D})] \times \rho$

(1) Where:

$\mathrm{A}=$ mass of oven-dried sample, $\mathrm{g}$

$\mathrm{B}=$ mass of surface-dry sample in air after immersion, g $\mathrm{C}=$ mass of surface-dry sample $\mathrm{i} \mathrm{n}$ air after immersion and boiling, $\mathrm{g}$

\section{IV.The Ultrasonic Pulse Velocity Test}

The test is applied according to ASTM C 597-2003 [20], on concrete cubes of $(100 \times 100 \times 100) \mathrm{mm}$, which are tested for the ultrasonic pulse velocity using ultrasonic apparatus. This research used the direct transmission to the $100 \times 100 \times 100$ concrete cubes . Recommendations for the use of this method were given in ASTM C 597-2003 [19].

$\mathrm{V}=\mathrm{L} / \mathrm{T}$

(2) Where

$\mathrm{V}=$ Ultrasonic pulse velocity, $\mathrm{km} / \mathrm{sec}, \mathrm{L}=$ Path length, $\mathrm{mm}$ and $\mathrm{T}=$ transit time, $\mathrm{sec}$.

\section{Results and Discussion}

\section{I.Fresh test Results}

The values of slump flow test were between 602 and $800 \mathrm{~mm}$ while T500 values range were between 2.2 and 6.8 seconds. Table 11 shows the slump spread values, T500, Blocking Ratio, Filling Height and V-Funnel for the produced mixes while the Table 12 showed typical Range of them. The test of blocking Ratio showed values range between 0.97 and 0.714 and Filling Height test values range between 3 and 40 . Results of SCC for all mixes with typical Range of them are shown in Table 7. V-Funnel test showed value ranges between 6.2 and 18 . These results shows that all mixes can produce SCC by using carbon fibers and mineral admixtures. As an exception, only mixes containing $12 \mathrm{~mm}$ long fibers were failed to produce selfcompacting concrete. The result showed that the three last mixes (MC0.5C12, MCS0.5C12, and MCM0.5C12) unlikely were not selfcompacted concrete mixes. the result of the mentioned above mixes were for slump flow test $(612,602,605)$ while the T500 values were $(6.4,6.8,6.7)$, blocking Ratio values were $(0.7,0.714,0.72)$, Filling Height values were $(36,40,41)$ and the time of filling V-Funnel were $(15,18,16) \mathrm{sec}$. High volumes of long carbon fibers are also blocking the exit of $\mathrm{V}$ funnel apparatus resulting in a decrease of flow time. The carbon fibers showed the most pronounced effect on the fresh state performance compared to the addition of mineral admixture performance compared to the addition of mineral admixture.

Table 12 Typical Range of fresh properties of SCC for all mixes

\begin{tabular}{cccc}
\hline \hline Method & Unit & \multicolumn{2}{c}{ Typical range of values } \\
\cline { 3 - 4 } & & Minimum & Maximum \\
\hline Slump flow & $\mathrm{mm}$ & 650 & 800 \\
T50 & $\mathrm{sec}$ & 2 & 5 \\
L-Box & $\mathrm{sec}$ & 0.8 & 1.0 \\
U-Box & $\mathrm{H} 2 / \mathrm{H} 1$ & 0 & 30 \\
V-Funnel & $\mathrm{H} 1-\mathrm{H} 2 \mathrm{~mm}$ & 6 & 12 \\
\hline
\end{tabular}

\section{II.Hardened concrete properties}

\section{The dry density}

The dry densities of 15 mixes were evaluated after 7 , 28, 90 and 180 days the results are in Table 13 and showed in Figure 2. It is obvious that the dry densities of the mentioned mixes are within the range of (23092576). All the results of test specimens, which presented in Table 13 and plotted in Figure 2 showed a continuous increase in the dry density with the progress of age. For example, the percentage increases in dry density for specimens after 28 days of curing measured relative to 7 days were ( $3.3 \%, 3 \% 4.32 \%$ and $1,88 \%)$ and ( $1.8 \% 1.75 \%, 2.6 \%$ and $1.17 \%)$ for (SCC0.1C6, SCCS0.1C6, SCCM0.1C6 and SCC0.1C12) and (SCC0.5C6, SCCS0.5C6, SCCM0.5C6 and SCC0.1C6) respectively. This behavior in the dry density of these specimens was believed to be mainly due to the continuity of hydration process, which forms a new hydration product within the concrete mass, which led to the increase of dry density with time. It is clear from Table 13 and Figure 2 that the addition of silica fume (SF) or high reactivity metakaoline (HRM) led to slightly increase in dry densities of self-compacting carbon 
fiber reinforced concrete mixes. For example, the percentage increases in dry density after 180 days of curing measured of (SCCS0.1C6, SCCS0.1C12 and SCCS0.5C6) and (SCCM0.1C6, SCCM0.1C12 and SCCM0.5C6) compared to self-compacting carbon fiber reinforced concrete without any mineral admixture were $(1 \%, 0.76 \%$ and $1,07 \%)$ and $(1.17 \%$, $0.95 \%$ and $1.47 \%$ ) respectively. This behavior is due to the pozzolanic activity of silca fume and high reactive metakaoline with calcium hydroxide, forming calcium silicate and alumina silicate hydrates released from cement hydration and filling voids among cement or other powder material particles.

This formulation resulting increase in density, leading to reduce in porosity and permeability. It is obvious observed from Figure 3 and 4 that the inclusion of carbon fibers to self-compacting concrete mixes led to slightly increase in the values of the dry density. For example, the percentage increase in values of dry densities of self-compacting carbon fiber reinforced concrete mixes (SCC0.1C6, SCCS0.1C6 and SCCM0.1C6) on 180 days of curing measured were $(0.45 \%, 0.56 \%$ and $0.51 \%)$ compared to self-compacting concrete without fibers (SCC, SCCS and SCCM) respectively. In addition, increasing fiber content from 0.1 to $0.5 \%$ led to more percentage increase in dry density values as shown in Figure 3. The percentage increase in dry densities values for (SCC0.5C6, SCCS0.5C6 and SCCM0.5C6) were $(0.80 \%, 0.87 \%$ and $1.11 \%)$ compared with (SCC0.1C6, SCCS0.1C6 and SCCM0.1C6) respectively for 180 days of curing period. On other hand, increasing fiber length from $6 \mathrm{~mm}$ to $12 \mathrm{~mm}$ led to slightly increase in the dry density as shown in Figure 4. For example, the percentage increase for $(\mathrm{SCC} 0.1 \mathrm{C} 12$, SCCS0.1C12 and SCCM0.1C12) were $(0.8 \%, 0.56 \%$ and $0.6 \%$ ) compared to (SCC0.1C6, SCCS0.1C6 and SCCM0.1C6) respectively for 180 days of curing period. This increases in dry densities were due to the high specific gravity of carbon fibers and a little air voids formation which be entered with the inclusion of carbon fibers.

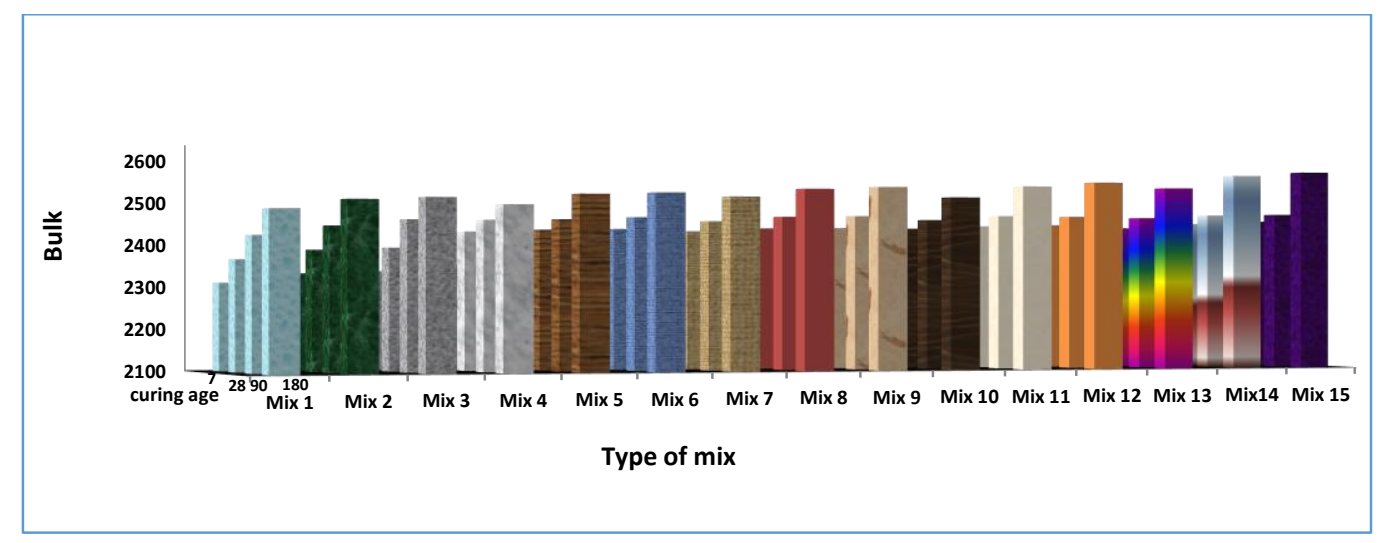

Figure 2: Effect of different curing period on air-dry density for SCC Mixes.

Table 13: Air density and Ultrasonic Pulse Velocity measurements for all SCC mixes at different age of curing

\begin{tabular}{|c|c|c|c|c|c|c|c|c|c|}
\hline \multirow[t]{2}{*}{$\overline{\mathrm{Mix}}$} & \multirow[t]{2}{*}{ Mixture code } & \multicolumn{4}{|c|}{$\begin{array}{c}\text { Air density } \mathrm{kg} / \mathrm{m}^{3} \text { at } \\
\text { ages } \\
\text { of }\end{array}$} & \multicolumn{4}{|c|}{$\begin{array}{l}\text { Ultrasonic Pulse Velocity } \\
(\mathrm{km} / \mathrm{s}) \text { at ages of }\end{array}$} \\
\hline & & $\begin{array}{c}7 \\
\text { days }\end{array}$ & $\begin{array}{c}28 \\
\text { days }\end{array}$ & $\begin{array}{c}90 \\
\text { days }\end{array}$ & $\begin{array}{r}180 \\
\text { days }\end{array}$ & $\begin{array}{c}7 \\
\text { days }\end{array}$ & $\begin{array}{c}28 \\
\text { days }\end{array}$ & $\begin{array}{c}90 \\
\text { days }\end{array}$ & $\begin{array}{r}180 \\
\text { days }\end{array}$ \\
\hline 1 & SCC & 2309 & 2365 & 2421 & 2481 & 4.66 & 5.29 & 5.57 & 5.83 \\
\hline 2 & SCCS & 2331 & 2387 & 2443 & 2503 & 4.71 & 5.38 & 5.60 & 5.88 \\
\hline 3 & SCCM & 2336 & 2392 & 2458 & 2508 & 4.52 & 5.40 & 5.63 & 5.90 \\
\hline 4 & SCC0.1C6 & 2352 & 2430 & 2457 & 2492 & 4.75 & 5.37 & 5.78 & 5.88 \\
\hline 5 & SCCS0.1C6 & 2364 & 2435 & 2459 & 2517 & 4.79 & 5.42 & 5.83 & 5.95 \\
\hline 6 & SCCM0.1C6 & 2336 & 2437 & 2464 & 2521 & 4.67 & 5.45 & 5.85 & 5.96 \\
\hline 7 & $\mathrm{SCC} 0.1 \mathrm{C} 12$ & 2387 & 2432 & 2455 & 2512 & 4.82 & 5.40 & 5.78 & 5.94 \\
\hline 8 & SCCS0.1C12 & 2394 & 2439 & 2466 & 2531 & 4.83 & 5.5 & 5.88 & 5.99 \\
\hline 9 & SCCM0.1C12 & 2356 & 2440 & 2468 & 2536 & 4.73 & 5.52 & 5.90 & 6.00 \\
\hline 10 & SCC0.5C6 & 2396 & 2439 & 2459 & 2512 & 4.83 & 5.50 & 5.85 & 5.94 \\
\hline 11 & SCCSO 5 C6 & 2403 & 2445 & 2469 & 2539 & 4.84 & 5.64 & 5.93 & 6.01 \\
\hline 12 & SCCM0.5C6 & 2386 & 2448 & 2468 & 2549 & 4.82 & 5.67 & 5.91 & 6.04 \\
\hline 13 & $\mathrm{MC} 0.5 \mathrm{C} 12$ & 2413 & 2441 & 2465 & 2536 & 4.86 & 5.61 & 5.87 & 6.00 \\
\hline 14 & MCS $0.5 \mathrm{C} 12$ & 2424 & 2452 & 2472 & 2567 & 4.89 & 5.72 & 5.97 & 6.08 \\
\hline 15 & МСМ0.5C12 & 2400 & 2458 & 2474 & 2576 & 4.82 & 5.75 & 5.99 & 6.11 \\
\hline
\end{tabular}




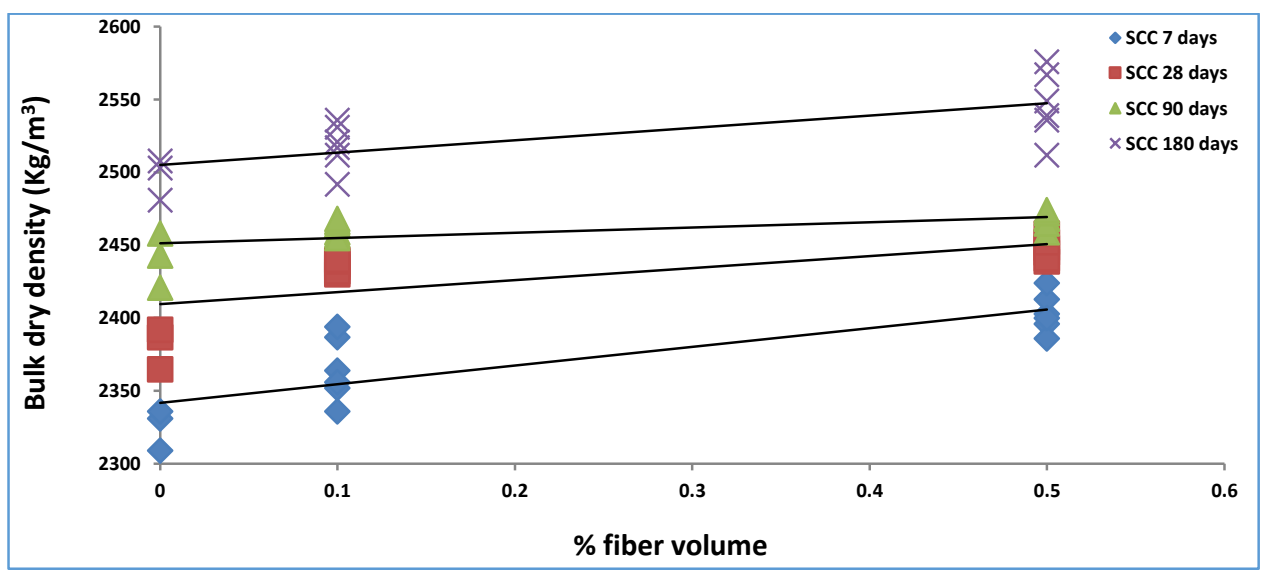

Figure 3: Effect of \% carbon fiber volume on air dry density for SCC Mixes

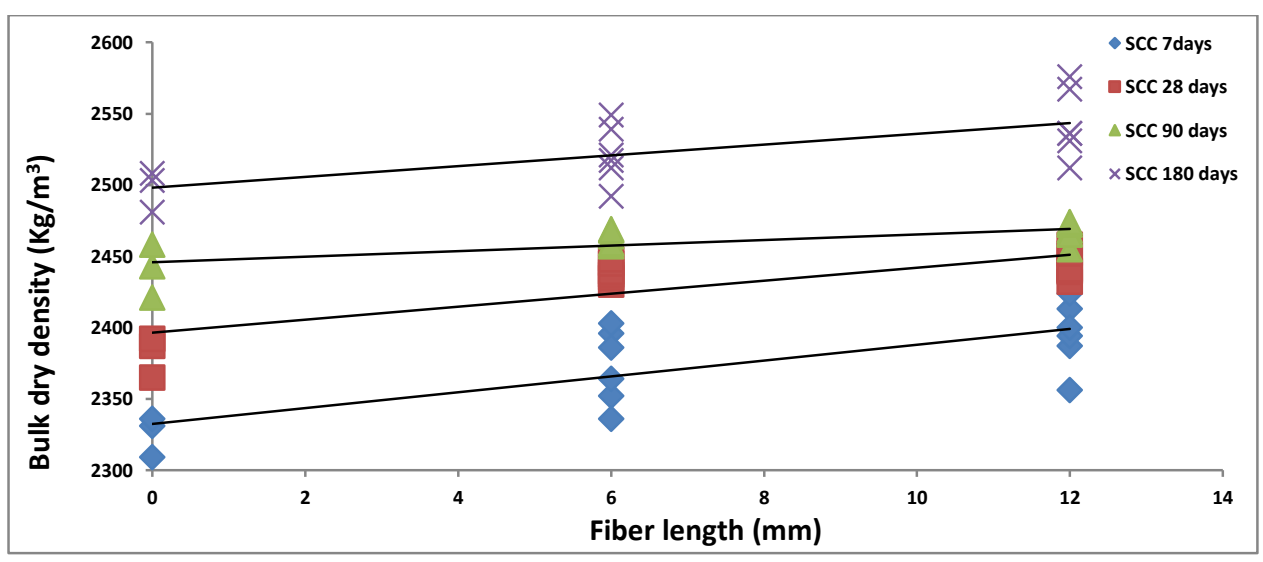

Figure 4: Effect of carbon fiber length on air-dry density of different curing period for SCC Mixes

\section{The ultrasonic pulse velocity}

Results of ultrasonic plus velocity test for all mixes cured in water for $7,28,90$ and 180 days are presented in Table 13 and plotted in Figure 5. All the ultrasonic pulse velocity test values are between $4.66 \mathrm{~km} / \mathrm{s}$ and $6.11 \mathrm{~km} / \mathrm{s}$ for all specimen. When using the proposed classification techniques which were suggested by Jones and Gatfield [11], all the self-compacted carbon fiber reinforced concrete mixes are excellent quality .From these test result it is observe that there are continuous increase in ultrasonic plus velocity values with the increase of time of curing. For example, the percentage increase in ultrasonic plus velocity after 180 days compared to 28 days of curing was $(9.5 \%, 9.8 \%, 9.35 \%$ and $10 \%)$ and $(8 \%, 6.56 \%$ and $6.52 \%)$ for (SCC0.1C6, SCCS0.1C6, SCCM0.1C6 and SCC0.1C12) and (SCC0.5C6, SCCS0.5C6 and SCCM0.5C6) respectively. This behavior is due to the improve of hydration which decreases the void space inside the self-compacted carbon fiber reinforced concrete mixes mass. Because of the velocity of ultrasonic inside materials is larger than that if it transfers inside space. The increase in gel/space ratio let to arise in wave speed and hence increase in ultrasonic plus velocity test values with time of curing. Figure 6 and 7 show that, the ultrasonic plus velocity test values of self-compacting carbon fiber concrete contain silica fume or high reactivity metakaoline are higher than that of self-compacting carbon fiber concrete without any supplementary materials. For example, the proportion increment for (SCCS0.1C6, SCCS0.1C12 and SCCS0.5C6) and (SCCM0.1C6, SCCM0.1C12 and SCCM0.5C6) after 180 days of curing measured compared to (SCC0.1C6, SCC0.1C12 and SCC0.5C6) were $(1.16 \%, 0.84 \%$ and $1,18 \%)$ and $(1.36 \%, 1.01 \%$ and $1.69 \%)$ respectively.

It is obvious from the result and the percentage increase of ultrasonic plus velocity test which mentioned before that ultrasonic plus velocity values for self-compacting carbon fiber concrete containing high reactivity metakaoline are higher than self-compacting carbon fiber concrete containing silica fume. Figure 6 and 7 show that, adding carbon fibers to self-compacting concrete lead to increase ultrasonic plus velocity test values .For example, The percentage increase in ultrasonic plus velocity of self-compacting carbon fiber reinforced concrete mixes (SCC0.1C6, SCCS0.1C6 and SCCM0.1C6) and (SCC0.1C12, SCCS0.1C12 and SCCM0.1C12) on 180 days of curing measured were $(0.85 \%, 1.19 \%$ and $1.01 \%)$ 
and $(1.89 \%, 1.87 \%$ and $1.70 \%)$ compared to selfcompacting concrete without fibers (SCC ,SCCS and SCCM) respectively. The increases in ultrasonic plus velocity are attribute to the increment in density due to the addition of carbon fibers, which led to increase in speed of ultrasonic pulse velocity wave. In other hand, Figure 6 shows that, increasing fiber content from $0.1 \%$ to $0.5 \%$ causing more increase in ultrasonic plus velocity of self-compacting concrete. The percentage increase in ultrasonic plus velocity values for (SCC0.5C6, SCCS0.5C6 and SCCM0.5C6) were $(1.02 \%, 1 \%$ and $1.34 \%)$ compared with
(SCC0.1C6, SCCS0.1C6 and SCCM0.1C6) respectively for 180 days of curing period. This behavior is due to the increase in density associated with the increase in fiber content from $0.1 \%$ to $0.5 \%$ causing a increase in speed of Ultrasonic Pulse Velocity wave. The same behavior were observed when increasing fiber length from $6 \mathrm{~mm}$ to $12 \mathrm{~mm}$.For example, The percentage of increase were $(1.02 \%, 0.672 \%$, $0.671 \%)$ for (SCC0.1C12, SCCS0.1C12 and SCCM0.1C12) compared to (SCC0.1C6, SCCS0.1C6 and SCCM0.5C6) after 180 days of curing period.

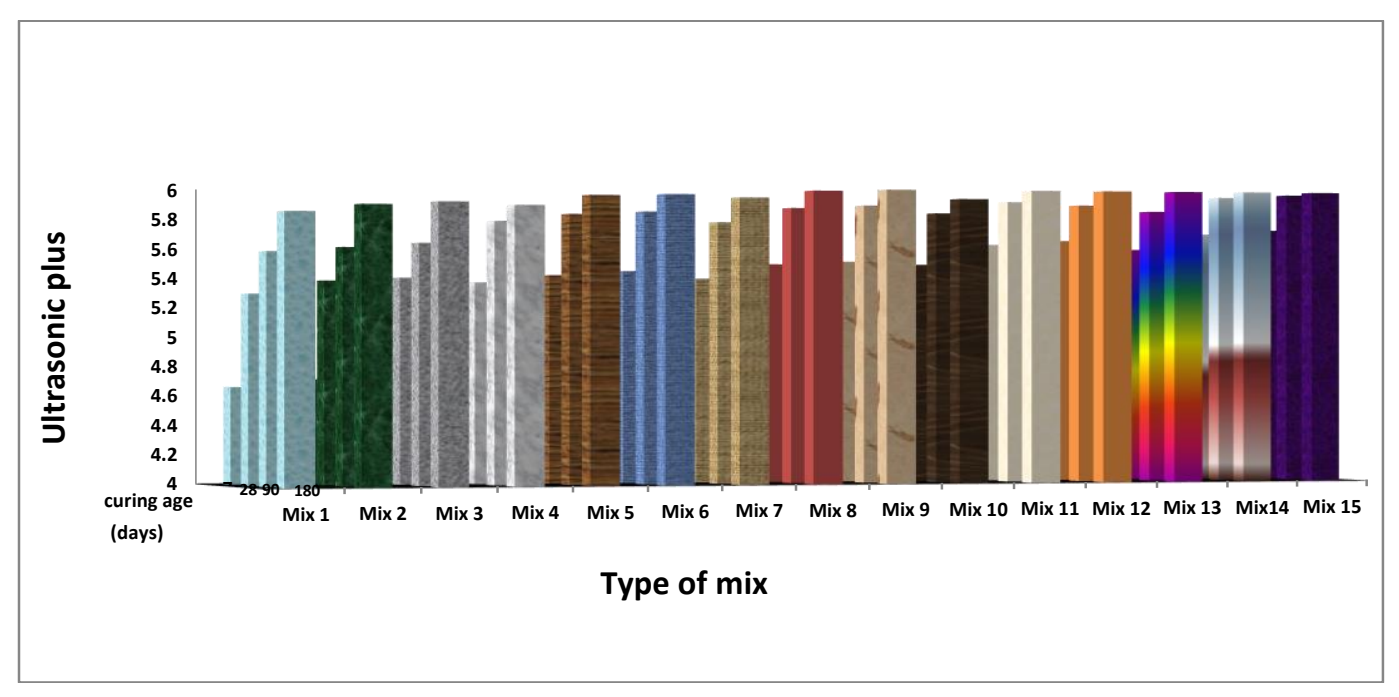

Figure 5: Effect of different curing period on Ultrasonic Pulse Velocity for SCC Mixes. Mixes

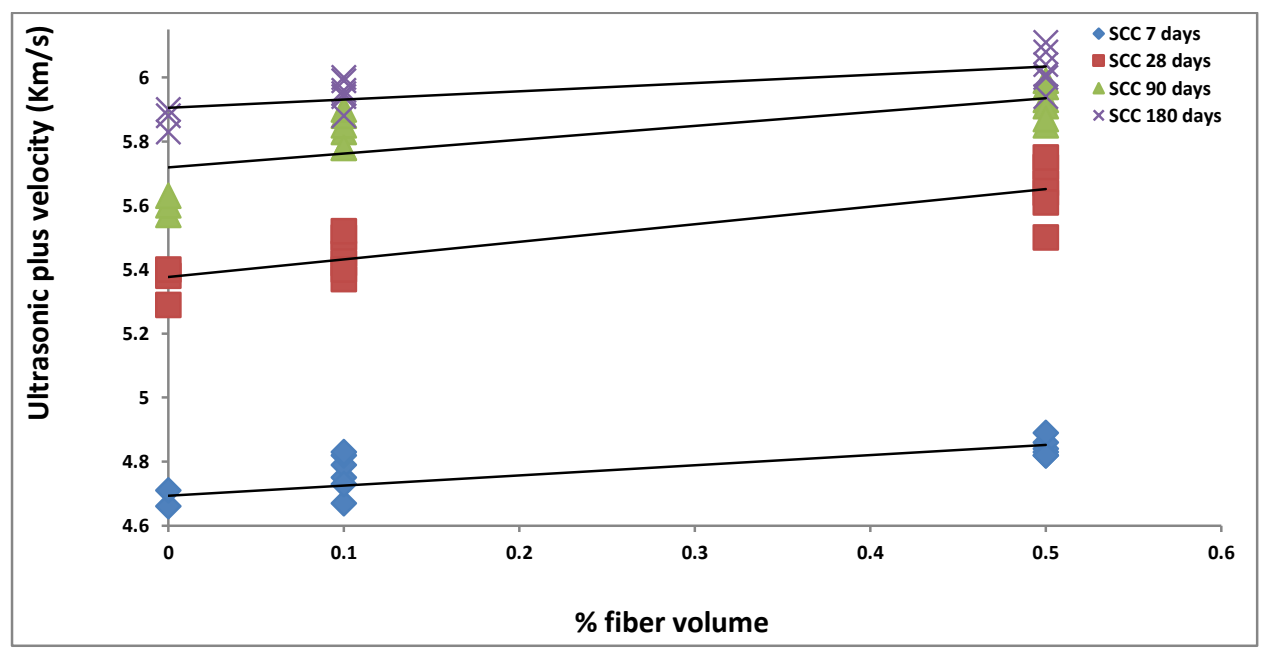

Figure 6: Effect of \% carbon fiber volume on UPV for SCC Mixes with different curing period 


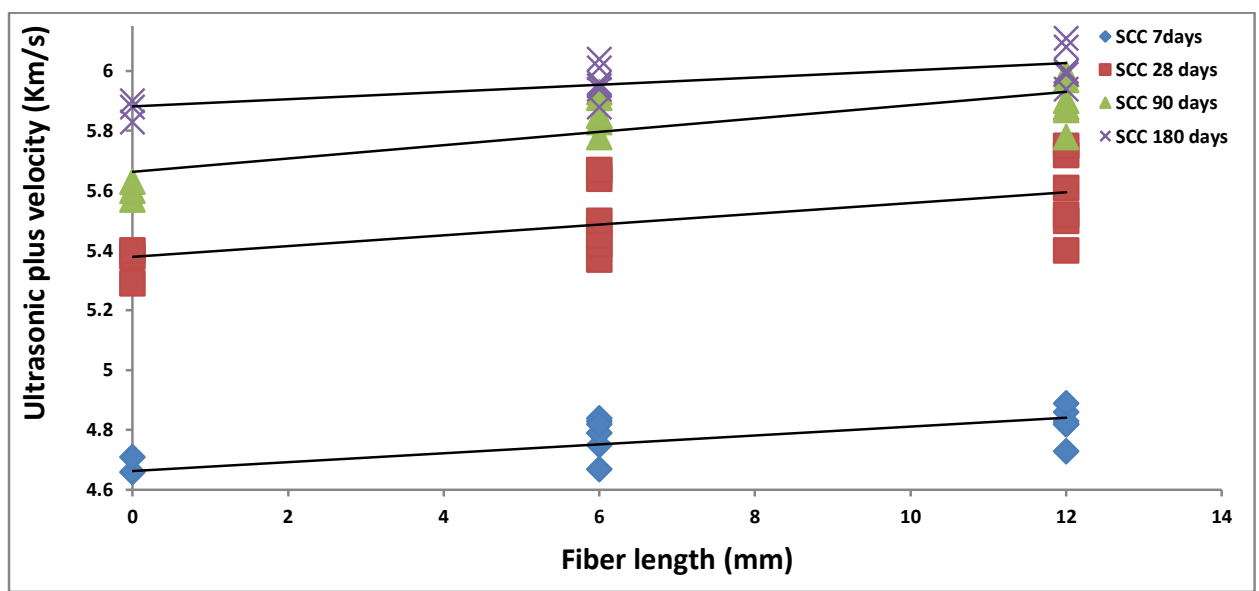

Figure 7: Effect of carbon fiber length on Ultrasonic Pulse Velocity of different curing period for SCC Mixes

3.The relationship between density and ultrasonic pulse velocity

It were obvious from Fig (8) that the higher the ultrasonic pulse velocity the higher the air density of the self compacting carbon fiber reinforced concrete and there was A linear correlation between ultrasonic pulse velocity and air density shown by the equation $\mathrm{y}=114.8 \mathrm{x}+1813(\mathrm{R} 2=0.808)$, where

$\mathrm{y}$ is the Ultrasonic pulse velocity and $\mathrm{x}$ the air dry density.

This is exactly coincident with the results of Panzera et al [13] who conclude a linear correlation between ultrasonic pulse velocity and air density in concrete.

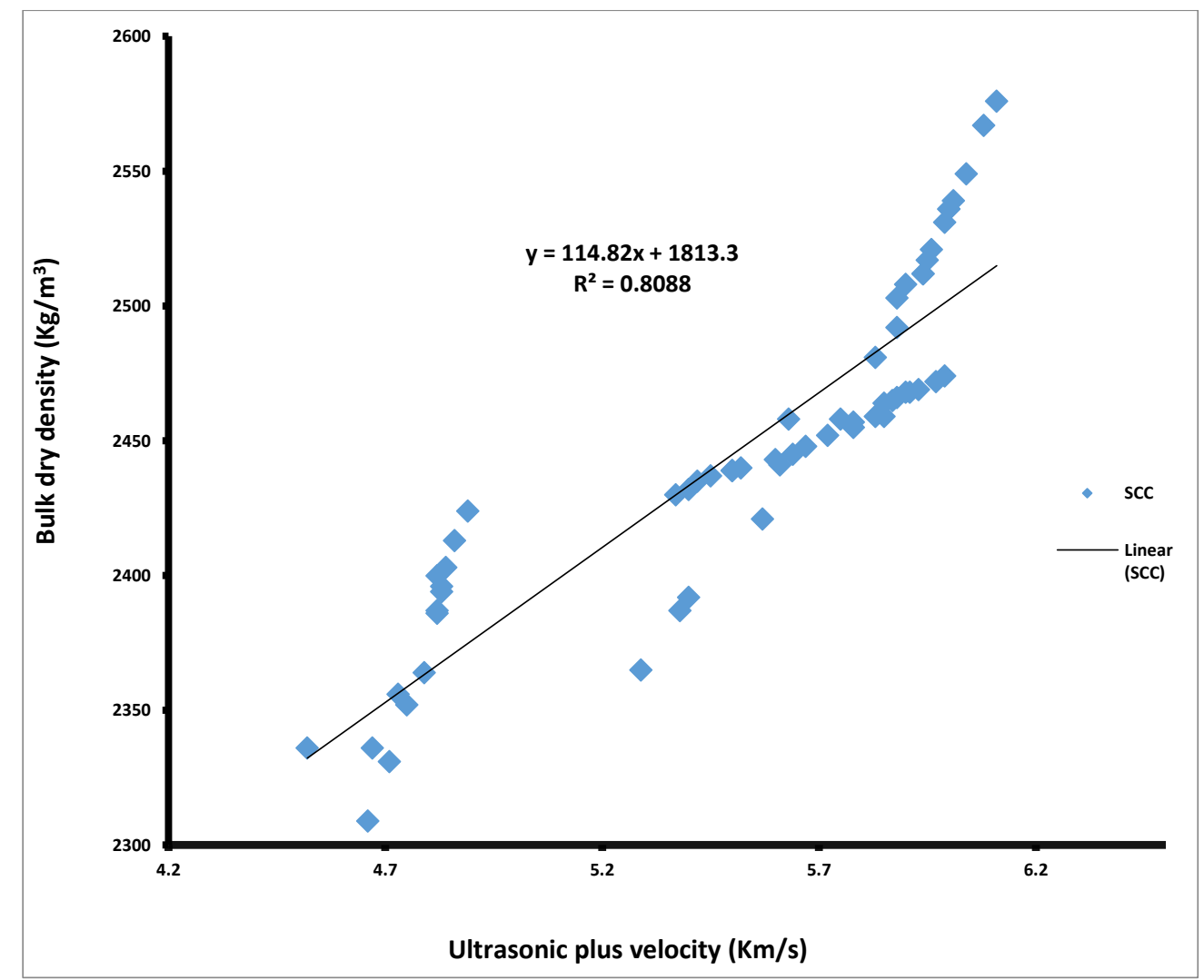

Figure 8: Relationship between UPV and density for all curing period and different SCC mixes 


\section{Conclusions}

Based on the results of this study the following conclusions can be written:-

1. The air-dry density of self-compacting carbon fiber reinforced concrete is higher than that of self-compacting concrete without fibers. The range of increase in this study were $0.85 \%$ to $3.31 \%$ at age $(7,28,90$ and 180$)$ days for all air-dry densities values of self-compacting carbon fiber reinforced concrete.

2. The increase in fiber content from $0.1 \%$ to $0.5 \%$ led to a slightly increases in air-dry density of self-compacting carbon fiber reinforced concrete values. The percentage increase of self-compacting concrete mixtures are between $(0.08 \%$ to $2.14 \%)$ at age $(7,28,90$ and 180$)$ days respectively.

3. In general, increasing fiber length from $6 \mathrm{~mm}$ to $12 \mathrm{~mm}$ led to improve air-dry density. This increase for selfcompacting carbon fiber reinforced concrete are from $0.12 \%$ to $1.5 \%$ at age from ( 7 to 180 ) days age.

4. The addition of carbon fibers to self-compacting concrete mixtures increases ultrasonic pulse velocity values. The range of increase are between $(0.74 \%$ to $5 \%)$ at age of 28 days.

5. In general, adding $0.5 \%$ of carbon fibers instead of $0.1 \%$ leads to increases in the ultrasonic pulse velocity in SCC mixes. The percentage increase for self-compacting concrete mixtures are (1\% to $4.05 \%)$ at different ages.

6. Increasing fiber length from $6 \mathrm{~mm}$ to $12 \mathrm{~mm}$ led to more increase in ultrasonic pulse velocity values. The percentage increase of self-compacting concrete mixtures due to increasing fiber length are (0\% to $1.48 \%)$ at different ages.

\section{References}

[1] M. Safiuddin, "High performance mortar with carbon fibers: Properties and mix optimization". Saarbrücken, Germany, 2010.

[2] Md. Zakaria and A.S. Abdul, "Flexural Response Of Hybrid Carbon Fiber Thin Cement Composites," Construction and Building Materials Vol. 25, Issue 2, pp . 670-677, 2011.

[3] W.I. Khalil and A. Abdulrazaq, "Mechanical Properties of High Performance Carbon Fiber Concrete," Eng \& Tech. Journal, Vol. 29, No. 5, 913, 2011.

[4] H.N. Abdullah, "Durability of Carbon Fiber Reinforced Self Compacting Concrete," MSc Thesis, Department of Building and Construction Engineering, University of Technology, 2013.

[5] M. Yakhlaf, "Development of Carbon Fiber Reinforced Self-Consolidating Concrete Patch for Repair Applications," Thesis presented to the University of Waterloo in fulfillment of the thesis requirement for the degree of master of applied science in Civil Engineering, Waterloo, Canada, 2013.
[6]The European Guidelines for Self-Compacting Concrete, Specification, Production and Use, 2005.

[7] D. Gao, L. Mo L, and L. Peng, "Mechanical And Electrical Properties Of Carbon Nano Fiber SelfConsolidating Concrete," In: Proceedings of the 12th International Conference on Engineering, Science, Construction, and Operation in Challenging Environments. Honolulu (USA); 2010. p.p 2577-2585.

[8]C. Chang, M. Ho, G. Song, L. Mo and H. Li. "Improvement of Electrical Conductivity in Carbon Fiber-Concrete Composites Using Self-Consolidating Technology," In: Proceedings of the 12th International Conference on Engineering, Science, Construction, and Operation in Challenging Environments. Honolulu (USA), pp 3553-3558, 2010.

[9] M. Yakhlaf, M. Saffiudin and K.A. Soudki, "Properties of Freshly Mixed Carbon Fiber Reinforced Self-Consolidating Concrete," Construction and Building Materials, in press, 2013.

[10] M. Yakhlaf, Md. Safiuddin, K.A. Soudki and A.El. Baden, "Case Study of Mechanical Properties of Carbon Fiber Reinforced Self-Consolidating Concrete," Proceedings of the 8th International RILEM Symposium on Self-Compacting Concrete (Flowing toward Sustainability).Washington, USA, 963-977, 2006.

[11] R. Jones and E. Gatfield, "Testing Concrete by Ultrasonic pulse Technique," London, Her Majesty's, stationary Office, 15-16, 1963.

[12] T.H. Panzera, J.C. Rubio, C.R. Bowen, W.L. Vasconcelos and K. Strecker, "Correlation between Structure And Pulse Velocity Of Cementations Composites," Advances in Cement Research, Vol. 20, No. 3, 101-108, 2008.

[13] Iraqi Specification, No. 5, Portland cement, 1984.

[14] Iraqi specification, No. 45, Aggregate from Natural Sources for Concrete and Construction, 1984.

[15] ASTM C 1240 - 05 "Standard Specifications for Silica Fume Used In Cementations Mixtures," Annual Book of ASTM Standards, pp. 1-7, 2007.

[16] ASTM C618-03, "Standard Specification for Coal Fly Ash and Raw or Calcined Natural Pozzolan for Use Concrete," Annual Book of ASTM Standard, Vol. 04-02, February 2003, pp.296-298.

[17] Sika Company, "Technical Data Sheet Catalogue," polypropylene, glass, carbon fibers, 2006.

[18] S. Grünewald and J.C. Walraven, "Parameter-Study on the Influence of Steel Fibers and Coarse Aggregate Content on the Fresh Properties of Self-Compacting Concrete," Cement and Concrete Research, Vol. 31, 2001, pp. 1793-1798

[19] ASTM C642-97, "Standard Test Method for Density, Absorption, and Voids in Hardened Concrete," Annual Book of ASTM Standards, V.04.02, 1-3, 2003. [20]ASTM C597-2003, "Standard Test Method for Pulse Velocity through Concrete," Annual Book of ASTM Standard American Society for Testing and Materials, Vol. 04. 02, 2003. 